\title{
Penerapan Teknologi Modular Dalam Konsep Perancangan Arsitektur
}

\author{
Dian Kusumowardani ${ }^{1}$ \\ ${ }^{1}$ Program Studi Arsitektur Institut Teknologi Budi Utomo \\ 1 dkusumowardani@yahoo.com
}

\begin{abstract}
ABSTRAK
Seiring dengan perkembangan teknologi di dunia saat ini telah mengubah pola hidup manusia, yang menuntut manusia untuk menggunakan teknologi dalam mewujudkan tuntutan kehidupan manusia yang lebih efisien, terampil dan lebih cerdas. Seiring dengan perkembangan teknologi pada rancang bangun arsitektur bangunan di dunia pada umumnya dan juga di Indonesia menjadi hal yang sangat menarik dengan modernisasi dan adanya adaptasi dari teknologi yang bersifat tradisional menuju penerapan teknologi yang modern sesuai tuntutan pemenuhan kebutuhan manusia akan kepraktisan dan efisiensi dalam dunia rancang bangun. Teknologi Modular pada rancang bangun arsitektur yaitu penerapan dimensi atau ukuran dasar berupa modul dasar yang digunakan sebagai dasar-pada perencanaan, sehingga dalam perancangannya modul dasar tersebut dapat berkembang menjadi dimensi modular yang merupakan kelipatan dari modul dasar menjadi jalan keluar akan tuntutan bangunan yang efisien, terampil dan lebih cerdas tersebut.
\end{abstract}

Kata kunci: teknologi, modular, perancangan, arsitektur

\section{ABSTRACT}

Along with the development of technology, the world has that has been enforced on us has changed our lives fundamentally to use technology to be more efficient and smarter in our interaction to live efficient. With the advancement of technologies in common architecture designs in the world as well as in Indonesia. Such advancements are essential with the modernisation and adaptation of technologies derivative from traditional roots through its application in the modern world, accompanying and appetizing the continuous demands of practicality and efficiency within architecture design. The modular technology in architecture design is the application of dimension and basic measurements in the form of a basic module that's us as a groundwork and core integral part of designing. So that in the process, it could be developed into a dimensional modular that's double the original module as a solution for the outpouring demand for it.

Keywords: technology, modular, design, architecture

\section{PENDAHULUAN}

\subsection{Latar Belakang}

Meningkatnya tuntutan manusia sebagai penghuni bangunan terhadap berbagai aspek bangunan yaitu tidak lagi hanya terhadap kenyamana, keamanan bahkan telah meningkat pada aspek efisiensi suatu bangunan dari mulai masa pembangunan sampai dengan saat gedung siap untuk digunakan sebagai wadah aktifitas di dalamnya sesuai fungsi gedung tersebut.

\subsection{Permasalahan}

Seiring dengan perkembangan teknologi dunia khususnya dalam teknologi struktur konstruksi penerapan teknologi tersebut harus dapat mendukung tuntutan pemenuhan kebutuhan terhadap berbagai aspek kbaik kenyamanan, keamanan termasuk efisiensi bangunan dari mulai tahap pembangunan sampai dengan saat bangunan tersebut digunakan.

Teknologi modular pada arsitektur yang menerapkan dimensi ukuran dasar berupa modul dasar dapat digunakan sebagai dasar-dasar di dalam perencanaan, sehingga dalam perancangannya modul dasar dapat berkembang menjadi dimensi modular yang merupakan kelipatan dari modul dasar untuk mencapai tuntutan efisiensi. 


\section{METODOLOGI}

Metode dalam penulisan jurnal ini menggunakan deskriptif kualitatif dengan melakukan analisis terhadap data literature melalui kajian pustaka dengan mengumpulkan data-data dari sumber primer. Sumber data yang digunakan berupa data dari buku, paper dan online yang kemudian diolah.

\section{ANALISA DAN PEMBAHASAN}

Penerapan sietem modular pada rancangan arsitektur telah diterapkan sejak zaman dahulu namun telah mengalami perkembangan pada masa sekarang yaitu pada masa dahulu modul ditetukan oleh besaran ukuran kolom dan jarak kolom yang berlaku pada saat itu sedangkan sekarang modul merupakan suatu kebutuhan karena adanya industry bahan-bahan bangunan (modular prefabrikasi) yang memerlukan koordinasi dari bermacam-macam bahan bangunan.

Kebutuhan dimasa sekarang menuntut pembangunan yang cepat dan efisien dengan tetap mempertahankan nilai-nilai arsitektur yang baik secara fungsi dan estetika bangunan, oleh karena itu diperlukan sistem penyelesaian bangunan secara praktis yaitu sistem koordinasi modul yang dapat menghemat waktu, biaya, bahan bangunan dan tenaga kerja.

Sistem ini mengatur semua komponen bangunan yang berhubungan satu dengan yang lain didalam ukuran-ukuran yang berdasarkan modul atau dimensi unit.

Meskipun sistem modular ini relatif baru dalam perkembangan industri dan belum secara luas diadopsi namun penggunaan sistem ini mulai dipakai khususnya di kota-kota besar yang telah berkembang dan membutuhkan sistem pembangunan yang lebih efisien dengan pengeluaran yang minimal.

Diluar dari keunggulannya sistem yang futuristik ini tentunya juga memiliki berbagai kelemahan. Kelebihan dan kelemahan ini harus dipahami terlebih dahulu sebelum pembangunan dengan teknologi modular diterapkan agar memperkecil kerugian.

\section{A. Efiensi Bangunan Modular dengan Material Pabrikan}

Sistem modular adalah metoda pelaksanaan pembangunan dengan memanfaatkan material atau komponen fabrikasi yang dibuat di luar lokasi proyek atau di dalam lokasi proyek namun perlu disatukan dahulu antar komponennya (erection) ditempat yang seharusnya pada konstruksi (Tatum dkk, 1987).

Konstruksi modular lebih mengacu kepada volumetrik sebuah ruang, bukan sebagai bagian ruang seperti tembok, atap, atau lantai, namun sebagai sebuah kesatuan ruang sebuah modular rata-rata telah diselesaikan $60 \%$ sd $90 \%$ diluar site yaitu di dalam pabrik kemudian di transportasikan dan dirakit di dalam site sebuah proyek (velamati, 2012)

Unsur-unsur arsitektur yang diukur dan dibuat sebagai perbandingan tidak hanya berdasarkan sifat-sifat serta fungsi strukturalnya saja, tapi juga oleh proses pembuatannya. Karena dibuat dalam jumlah massal di pabrik maka memiliki ukuran-ukuran dan proporsi standar yang dikenakan padanya foleh para produsen perseorangan maupun industri.

Modul dasar harus menjadi satu dan mencapai tingkat kecocokan yang tinggi dalam konstruksi sebuah bangunan maka ukuran standar dan proporsi dari unsur-unsur yang diproduksi di pabrik akan mempengaruhi ukuran, proporsi dan jarak bahan -bahan lainnya juga. Pintu dan jendela standar harus diberi ukuran dan proporsi yang pas di dalam modul bukaan tembok. Kayu atau logam penopang harus diberi jarak untuk menerima modul bahan tersebut.

Berkembangnya modul-modul material fabrikasi menimbulkan pemahaman bahwa proses pembangunan bangunan modular lebih cepat dan hemat, baik dari segi biaya maupun waktu konstruksi, daripada bangunan yang tidak menggunakan modul 


\section{B. Peran Modular Pabrikasi dalam Upaya Penghematan Energi dan Limbah Material}

Sistem pabrikasi dalam pembangunan bangunan modular dapat tidak hanya sama atau lebih unggul dari bangunan tradisional dalam segi kualitas, tetapi dengna proses manufaktur yang terkontrol sangat meminimalisir energi dan limbah material selama proses konstruksi dilapangan. Modularitas dalam sistem konstruksi memungkinkan relokasi dan re-use bangunan tanpa melakukan demobilisasi dan pembuangan limbah sehingga dapat menghemat energi.

Melalui penyusunan elemen-elemen arsitektural secara bermodul untuk memudahkan bongkar pasangnya. Ruang modular yang terbentuk sebenarnya merupakan gabungan dari beberapa susunan modul yang dapat dibagi lagi seperti modul panel dindin, lantai. Modulmodul ini telah di set pada ukuran tertentu secara fabrikasi sehingga dapat langsung dirangkai dilapangan tanpa memodifikasi dimensi dengan system ini tidak ada lagi limbah material dari proses konstruksi karena modul-modul yang sudah terukur dari awal.

Namun terkait biaya konstruksi dengan menerapkan modular dapat jauh diatas konstruksi konvensional.

\section{KESIMPULAN}

Seiring dengan kemajuan teknologi menuntut terpenuhi. Unsur efisiensi baik terhadap biaya, mutu, dan waktu baik dari tahap perencanaan sampai dengan pelaksanaan pembangunan sebuah bangunan penerapan konsep modular pada bangunan arsitektur dapat mewujudkan tuntutan tersebut yaitu bangunan yang aman nyaman dan cerdas serta efisien.

\section{DAFTAR PUSTAKA}

Tatum dkk, 1987, Improving Constructibility During Conseptual Planning, Journal \& Construction Engineering and Management, Vol 113

Velamati, 2012, Feasibility, benefit and challenges of Modular USA

Matondang Zulkifli,2012, Konstruksi Bangunan Gedung,Unimed Press, Medan

Tambubolon MAW, 2017, Pengembangan E Module konstruksi Bangunan, Jurnal UNJ, Jakarta

Astuti Sri, 2018, Konsep modular dalam perancangan Arsitektur, id.scribd.com

Dwi Saputra Riski, 2019. Konsep modular dalam perancangan Arsitektur, id.scribd.com 
Dian Kusumowardani

Penerapan Teknologi Modular dalam Konsep Perancangan Arsitektur 